\title{
Business and Energy Efficiency in the Age of Industry 4.0: The Hulten, Broweus and Van Dijk Sensory Marketing Model Applied to Spanish Textile Stores during the COVID-19 Crisis
}

\author{
Gloria Jiménez-Marín ${ }^{1}$ (D), Rodrigo Elías Zambrano ${ }^{1}$, Araceli Galiano-Coronil ${ }^{2}$ (D) and Rafael Ravina-Ripoll ${ }^{3, *(\mathbb{D})}$ \\ 1 Audiovisual and Advertising Department, Faculty of Communication, University of Seville, 41012 Seville, \\ Spain; gloria_jimenez@us.es (G.J.-M.); rodrigoelias@us.es (R.E.Z.) \\ 2 Marketing and Communication Department, and INDESS, University of Cádiz, 11405 Jerez de la Frontera, \\ Spain; araceli.galiano@uca.es \\ 3 Business Organization Department and INDESS, University of Cádiz, 11405 Jerez de la Frontera, Spain \\ * Correspondence: rafael.ravina@uca.es
}

Citation: Jiménez-Marín, G.; Elías Zambrano, R.; Galiano-Coronil, A.; Ravina-Ripoll, R. Business and Energy Efficiency in the Age of Industry 4.0: The Hulten, Broweus and Van Dijk Sensory Marketing Model Applied to Spanish Textile Stores during the COVID-19 Crisis. Energies 2021, 14, 1966. https:/ / doi.org/10.3390/en14071966

Academic Editor:

Konstantinos Salonitis

Received: 15 February 2021

Accepted: 29 March 2021

Published: 2 April 2021

Publisher's Note: MDPI stays neutral with regard to jurisdictional claims in published maps and institutional affiliations.

Copyright: (c) 2021 by the authors. Licensee MDPI, Basel, Switzerland. This article is an open access article distributed under the terms and conditions of the Creative Commons Attribution (CC BY) license (https:// creativecommons.org/licenses/by/ $4.0 /)$.

\begin{abstract}
Strategic and tactical factors come into play in shop competitiveness where, in addition to the products sold, other marketing mix variables must also be considered. There are also subjective factors, such as perceptions through the senses. This became even more important when, as a result of the COVID-19 crisis and the forced closure of certain establishments with physical sales, it was necessary to increase profitability and efficiency. The aim of this study was to determine the exact role of sensory marketing in shop efficiency and profitability, based on the guiding principles of technology, innovation, and respect for the environment. We conducted an exploratory and experimental study consisting of the creation of a sensory strategy through the adaptation of the Hulten, Broweus and Van Dijk model on a specific establishment in the current era of Industry 4.0. The results indicate an increase in sales as well as customer satisfaction and happiness after implementing the relevant strategies. The conclusions show that this model is valid and reliable for physical retail establishments, and that these business strategies can significantly contribute to the optimisation of energy resources.
\end{abstract}

Keywords: Industry 4.0; sensory marketing; COVID-19; retail; merchandising

\section{Introduction}

Industry 4.0 has brought with it a series of competitive advantages for companies in the digital society, especially in terms of the optimisation and flexibility of manufacturing, supply and business processes [1,2]. Among these advantages, it is worth pointing out two aspects: first, that one of the great challenges faced by large companies that intend to implement an Industry 4.0 management model is the establishment of a robust level of energy efficiency in the daily development of their manufacturing activities [3]; second, that the robotization and automation of production processes not only exponentially improves organisational efficiency, but also reduces labour inputs and downtime [4]. In this regard, it is worth noting that several academic studies on Industry 4.0 empirically show that new technological changes pose significant threats to job quality and people's subjective happiness, unlike innovations in the past [5-7]. This is particularly relevant at the present time in the wake of the current COVID-19 pandemic - an unexpected scenario that will undoubtedly bring about major changes in the configuration of supply chains, and in the design of strategic management models in small and large companies [8,9].

In this context, it should also be added that consumption patterns are rapidly changing in today's digital society [10]. Given this reality, it is not surprising that companies in the Industry 4.0 era, especially retail companies, are in a permanent cycle of the technological innovation of their products or services. Thus, these entities will have less economic 
and financial risk of being absorbed by their competitors, including large multinational companies [11].

A basic premise for achieving this goal is the implementation of a set of commercial strategies based on the 7 variables of the retail marketing mix (hereafter referred to as the 7Ps) $[12,13]$. One of the most widely used marketing techniques is currently merchandising, whereby company managers aim to directly influence the behaviour of their potential customers [14]. Recognising this, it should be noted that we live in a market saturated with information, advertising and commercial offers, which makes merchandising less effective when attracting a significant volume of new customers [15,16].

Previous research has shown that the low efficiency of this particular marketing and advertising technique is caused by the fact that the business competitiveness of establishments involves other elements of a strategic, operational and tactical nature that are different from those of the products offered in today's digital society [17-19]. As a result of this heuristic knowledge, Krampe [20,21], among others, shows that sensory marketing can play a very important role in capturing the attention of customers. This is because a significant proportion of the purchases made by humans are made irrationally and driven by the senses and the positive emotions generated by the products or services [20,21].

\section{Literature Review}

According to Lindstrom [22,23], sensory marketing emerges as an attractive commercial tool that aims, through the senses, to generate a set of positive sensations and emotions in consumers that holistically stimulate not only the purchase of products or services, but also loyalty towards the brand [24]. In order to measure the responses of our brain to these stimuli of subjective wellbeing towards the brand, large multinationals began to use neuromarketing at the beginning of the 21st century to detect customers' consumption motives from a cognitive point of view [25].

With this new technology, the senses of hearing, taste, touch, and smell become particularly relevant for the implementation of new advertising campaigns in the era of Industry 4.0, especially in the audiovisual sector [26-29]. In this regard, numerous studies have found a strong link between physiological responses and human perceptions of the reality of things when it comes to carrying out the act of purchasing [30]. This discovery, and many others, has sparked a rich academic debate in the disciplines of economics, marketing and communication about the social benefits and competitive advantages that neuromarketing can offer for building innovative, sustainable and high-tech ecosystems. As a result, the concepts of customer experience management proposed by Schmitt [31] and Gobé's emotional branding [32] have emerged. In line with this research, Hulten, Broweus and Van Dijk [33] point out that sensory marketing is a very captivating marketing technique for companies to undertake commercial management models that revolve around the idea that their products should be sources of positive emotions for their customers and, therefore, of individual happiness. It is therefore not surprising that there has been a proliferating literature in recent decades on the empirical study of consumers' reactions after visualising products [27], the analysis of the emotional neuromarketing-branding construct [34] and the application of sensory marketing in the context of Industry 4.0 [35].

On the other hand, other authors have academically explored the theoretical framework of social marketing from the trinomial of consumption, economic profitability and organisational efficiency [36-38]. Technological advances and the automation of productive processes have direct effects on the quality of employment, climate change, social inequalities etc. [39-41]. In this line, it is worth drawing attention to the fact that in mid-2011 the German government promoted the "Industry 4.0 " strategic plan to boost its economy through the massive use of artificial intelligence, industrial robots and digital technology [42-45]. This meant the implementation of business strategies underpinned by the guiding principles of sustainability, environmental protection and consumer persuasion through sensory marketing [46]. 
Sensory merchandising has contributed significantly to the latter. The use of this marketing tool by retail companies encourages customers to spend more time inside their shops. This is highly important because it increases the likelihood of purchase and thus future sales figures in a landscape characterised by online sales [18,47-50]. Sensory merchandising also invigorates the creation of an atmosphere of pleasure and happiness for customers during their physical stay in shops. In this regard, it is worth noting that people who associate product consumption with hedonistic happiness or subjective wellbeing have high levels of brand loyalty. This phenomenon cannot be achieved through e-commerce, the activity of which has intensified exponentially with the unexpected inclusion of COVID-19 in our lives [5,51].

In light of what has been argued in the last lines of the previous paragraph, and as a corollary to this epigraph, it is the right time to draw attention to the fact that the health crisis caused by COVID-19 has led to the physical closure of many shops in the globalised world. This decision has led to the economic bankruptcy of many retail companies that were exclusively carrying out their sales within their own premises. In this regard, it is worth noting that many of the retail corporations that have survived this health tsunami have basically achieved so due to two factors. The first is that many retail organisations make a managerial decision to engage in emotional marketing in order to improve their bottom line in the era of Industry $4.0[7,52,53]$. The second is that a significant number of these organisations have invested heavily to adapt quickly to e-commerce [54]. This is a business strategy that can contribute significantly to the optimisation of energy resources and the robotization of production processes $[18,19,55]$. Both factors can be made more viable with the help of sensory marketing, if they go hand in hand with the creation of establishments with happiness management certificates.

\section{Research Objectives}

Sensory marketing is of great importance in people's purchasing decisions and in attracting consumers to points of sale [38]. On this basis, we set out to explore the empirical influence of sensory marketing on the implementation of positive experiences in physical points of sale, especially in the wake of the debacle of shop closures in Spain due to the COVID-19 crisis. From a management perspective, this information allows us to design a strategic marketing plan that helps to improve the corporate image of organisations in the Industry 4.0 timeframe and minimise resources, thereby optimising their management and making them healthier and more sustainable [56].

In this sense, once this exploration has been carried out, our main objective is to demonstrate that sensory marketing strategies have their raison d'etre in arousing positive emotions and sensory stimulation in consumers, thereby generating more efficient purchases [57].

The third objective is to adapt Hulten, Broweus and Van Dijk's Sensory Marketing Model [33] to a current case, showing how technology, innovation and respect for the environment must become the driving forces behind the economic viability of the model [58].

Based on the Hulten, Broweus and Van Dijk Sensory Marketing Model [33], this research aims to measure and analyse the following ratios in Aristocrazy shops: average time spent in the establishment, customer satisfaction and sales volume. Once this information has been obtained, it will be possible to explore the influence of the sensory marketing tactics undertaken by the entity under study to invigorate sales in its physical shops. This requires facilities with renewable energy systems and environmental quality [59].

\section{Methodology}

In this sector, one of the basic aims of sensory merchandising is to create an atmosphere inside the shops that holistically stimulates customers' desire to buy [60]. So, based on the model of Hulten, Broweus and Van Dijk [33], we decided to empirically analyse the effectiveness of the sensory marketing techniques used by the company Aristocrazy in the establishments they have in the cities of Seville and Barcelona. The choice of these two 
points of sale was justified for three reasons. The first is that their spatial dimensions are very similar. Secondly, they have the same number of employees (i.e., four people-all women). Lastly, their target public is female, upper-middle class and with an age ranging from 12 to 45 years old.

In order to understand the perceptions and emotions of the customers provoked by the sensory stimuli provided by the shops in our study [61,62], a documentary, exploratory, quasi-experimental and causal-quantitative analysis was carried out. In conjunction with the above, an examination of the potential customers who visit the Aristocrazy shops selected for this research was made based on two methodological criteria. Firstly, that the customers chosen for this study come from a similar socio-economic stratum. Secondly, that the analysis was carried out not only on the same days of the week, but also in the same time frame.

Once the sample population was chosen, the next step was to choose the parameters to be examined in order to empirically verify the fulfilment of the set objectives. To this end, the ratios of Hulten, Broweus and Van Dijk's model [33] were chosen. These indicators are the following: average time spent in the shop, customer satisfaction and sales volume. In order to measure the time spent in the store, a system for recording the time of entry and time of exit was used. The cameras located at the entrance of the Aristocrazy shops contributed greatly to this task. The customer satisfaction variable was measured using a questionnaire adapted from Kelley and Davis, whose questions are based on a Likert scale from 0 to 7 points [63]. Likewise, the sales volume was assessed by the economic cash control system, which offers a wealth of information to evaluate how the sensory marketing actions implemented by Aristocrazy for this scientific experiment influence its sales volume in the short term.

In accordance with these indicators and the theoretical framework of this research, the data collection was carried out during the month of September 2020, specifically on Mondays 7 and 14 September (12:00-14:00), Tuesdays 8 and 15 September (12:00-14:00) and Wednesdays 9 and 16 September (18:00-20:00). In this line, it should be noted that we reached an agreement with the management of these Aristocrazy shops so that during the selected days of September 2020 they would not carry out any promotional campaigns, discounts or any other techniques associated with the price ratio.

The survey respondents reporting on their satisfaction with the shopping experience in the experiment comprised 18 people: 9 in Seville and 9 in Barcelona. Although the sample may appear to be small, it should be taken into consideration that this is an experimental design and builds on previous and recent research such as that carried out by Fahrur and Marlina [64] or Rodas-Areiza and Montoya-Restrepo [65].

A summary of their characteristics is shown in Table 1.

Table 1. Sample composition.

\begin{tabular}{ccccccccccc}
\hline & Age & Gender & Ec-Soc. Class & Age & Gender & Ec-Soc. Class & Age & Gender & Ec-Soc. Class \\
\hline Barcelona & 16 & F & Medium & 24 & F & M-H & 19 & F & Medium \\
\hline Barcelona & 30 & F & M-H & 37 & M & Medium & 33 & F & M-H \\
\hline Barcelona & 42 & F & M-H & 40 & M & M-H & 44 & F & M-H \\
\hline Seville & 14 & F & Medium & 21 & F & Medium & 17 & F & Medium \\
\hline Seville & 25 & F & M-H & 29 & M & M-H & 32 & M & Medium \\
\hline Seville & 37 & F & H & 40 & F & M-H & 41 & F & M-H \\
\hline \multicolumn{7}{r}{ Ec-Soc. Class: Social and economic class. * M: Male; F: Female. * M-H: Medium-High } &
\end{tabular}




\section{Results}

This section presents the most relevant results of this research. The sensory marketing campaign that was developed during the examined week was based on the sensory experience-the search for the connection of emotions in consumers, leaving aside the logical attributes of the products as sales arguments. In this way, functional attributes are set aside, and an attempt to transform the product into an experience that places the human brain at the centre of the action is made, registering the brand in terms of mental conceptions.

The sensory aspects covered were as follows:

- Smell: A distinctive air freshener was applied. In order to define the fragrance, an indepth interview was conducted with the head of Sandir Olfatory Branding, a company dedicated to the creation of corporate fragrances. In the context of Aristocrazy, it was possible to activate or calm the atmosphere; it was decided, in accordance with the specialist, to calm it in order to make customers stay longer in the establishment.

- Sight: This sense was explored in two ways. First, the shop window. Given that visual marketing begins on the outside of an establishment, it was decided to design a window display that would arouse curiosity. To this end, and as both corners are establishments within a multi-brand surface, the use of this space was contracted with El Corte Inglés, for which the window dressing company Neuttro was hired. The second modifier of sight was product rotation. In order to achieve an atmosphere of constant renewal in the establishment that would motivate the customer to visit the shop more frequently, the mobility policy was determined as a maximum of 2 days. That is, the same product could not be in the same place for more than two days.

- Listening: A playlist was created according to the musical tastes of the target. This choice was based on a study on cultural consumption habits (we focused on music) carried out in 2020 by the Fundación Autor-SGAE [66]. The music followed the following parameters: the songs were those that the report found to have the highest audience and requests on the radio and the most purchased and downloaded on Spotify and iTunes; the volume of the music should not be excessive (no more than 50 decibels); finally, the rhythm of the songs varied according to the traffic of people in the establishment, with more intense and rhythmic songs being played at times of high traffic and other slower songs during quieter periods in the commercial space.

- Touch: To ensure that potential buyers could touch the products likely to be sold, the display shelves and furniture were lowered to a height above the shoulders of a person of average height $(1.68 \mathrm{~m})$, leaving only those products where the sense of sight was intended (i.e., products to be seen) and all others in a position where touching the product would be easy and accessible. In addition, a display with accessory products was installed next to the checkout counter so that people could touch complementary products while paying for other products (and thus stimulate impulse and low-involvement sales).

- Taste: No taste-based sensory marketing measures were carried out due to the nature of the products being sold.

Having explained in detail the sensory marketing action carried out, the next question to develop is regarding the monetary results of this campaign. The results show its economic success, both in the Seville establishment and in Barcelona. This can be seen in Table 2 and Figures 1 and 2. 
Table 2. Comparative data for the two Spanish cities before and after the experiment.

\begin{tabular}{|c|c|c|c|c|c|c|c|}
\hline & Date & Sales & Time Spent & $\begin{array}{c}\text { Customer } \\
\text { Satisfaction }\end{array}$ & Sales & Time Spent & $\begin{array}{c}\text { Customer } \\
\text { Satisfaction }\end{array}$ \\
\hline & & & Seville & & & Barcelona & \\
\hline \multirow{3}{*}{ 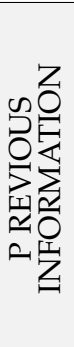 } & $\begin{array}{c}\text { Monday } \\
7 \text { September } 2020 \\
\text { 10:00-12:00 } \\
\end{array}$ & EUR 400.10 & $\min$ & $5 / 7$ & EUR 796.07 & $17 \mathrm{~min}$ & $5 / 7$ \\
\hline & $\begin{array}{c}\text { Tuesday } \\
8 \text { September } 2020 \\
12: 00-14: 00\end{array}$ & EUR 328.15 & $9 \min$ & $5 / 7$ & EUR 692.45 & $14 \mathrm{~min}$ & $5 / 7$ \\
\hline & $\begin{array}{c}\text { Wednesday } \\
9 \text { September } 2020 \\
18: 00-20: 00 \\
\end{array}$ & EUR 481.90 & $10 \mathrm{~min}$ & $6 / 7$ & EUR 865.32 & $13 \mathrm{~min}$ & $4 / 7$ \\
\hline \multirow{3}{*}{ 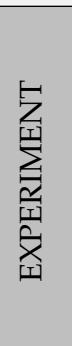 } & $\begin{array}{c}\text { Monday } \\
14 \text { September } 2020 \\
\text { 10:00-12:00 }\end{array}$ & EUR 627.50 & $16 \min$ & $7 / 7$ & EUR 956.23 & $21 \mathrm{~min}$ & $6 / 7$ \\
\hline & $\begin{array}{c}\text { Tuesday } \\
15 \text { September } 2020 \\
12: 00-14: 00\end{array}$ & EUR 490.05 & $11 \mathrm{~min}$ & $7 / 7$ & EUR 848.05 & $24 \mathrm{~min}$ & $7 / 7$ \\
\hline & $\begin{array}{c}\text { Wednesday } \\
\text { 16 September } 2020 \\
\text { 18:00-20:00 }\end{array}$ & EUR 546.80 & $14 \mathrm{~min}$ & $6 / 7$ & EUR 1135.65 & $19 \mathrm{~min}$ & $7 / 7$ \\
\hline
\end{tabular}

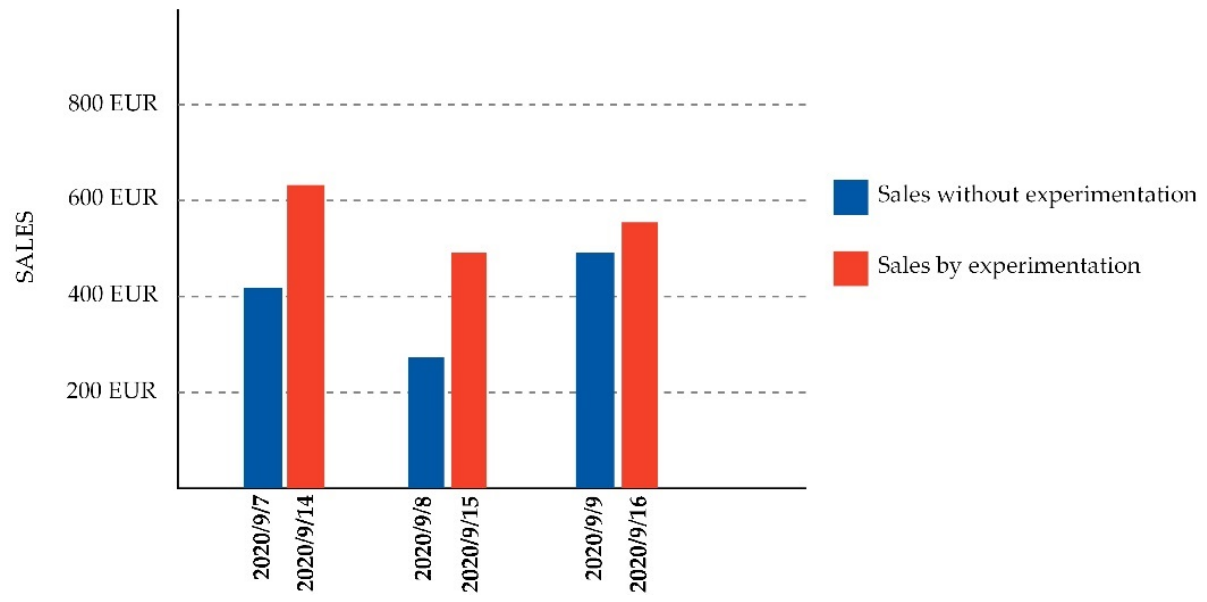

Figure 1. Sales evolution after experimentation in Seville.

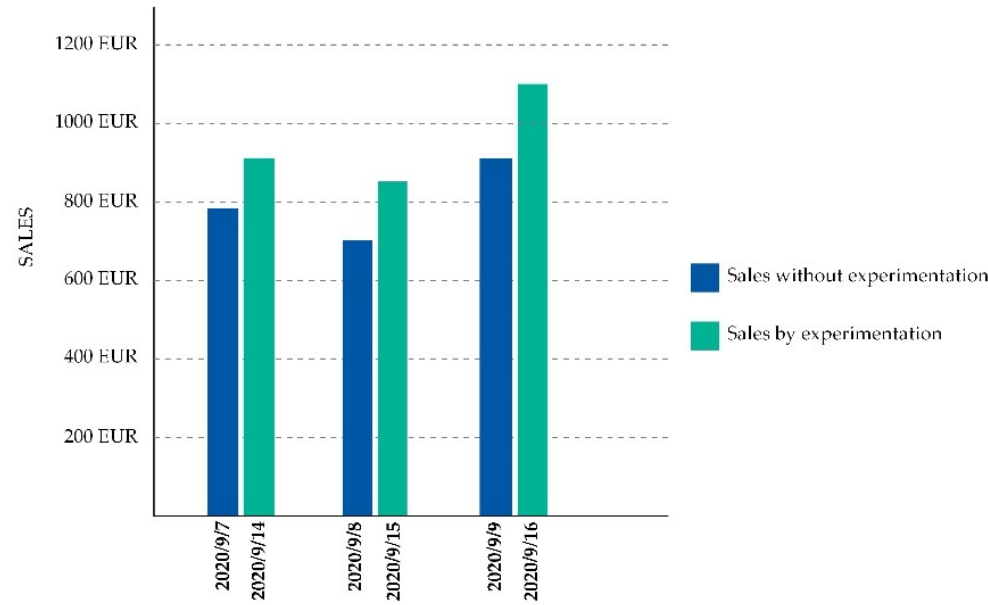

Figure 2. Sales evolution after experimentation in Barcelona. 


\section{Discussion}

Since this research is based on a practical case of the execution of an experiment using a model that has previously given results, and given that in the light of the data obtained, all these practices were shown to be economically profitable initiatives, it would be interesting to continue carrying them out in other types of commercial establishments or even in shopping centres, since in the near future (i.e., after COVID-19) all spaces will be very important, and there is special interest in those establishments that offer open spaces or spaces designed more for the experience and enjoyment rather than for the business itself. Similarly, in order to attract customers, it would be interesting to look for responsible energy facilities, with energy infrastructures with renewable and green energies that favour the seduction of customers towards their surroundings.

Although from an academic perspective all empirical results are expected to be economically and statistically significant, this article presents the economic benefit through the evaluated sensory marketing campaign because it is an experimental project that aims to lay the foundations for a subsequent larger experiment with an optimal sample size calculated from the determination of the standard error defined by the triangulated methodology consisting of experiment-interview-survey. This will take place, as indicated, in a second phase.

\section{Conclusions}

Several conclusions can be drawn from the data above. Firstly, it has been clearly stated that the evening public tends to spend more than the public that comes to shop in the morning, and also tend to stay longer and to value changes better. Based on this, it was possible to observe how the three items measured (sales, time spent and satisfaction) increased after the application of the sensory marketing strategy, both in a city in the north of Spain (Barcelona) and in a city in the south (Seville).

The increase in sales in both establishments was as follows: in the city of Seville, a total of EUR 454.20 was obtained, and in Barcelona, a total of EUR 586.09. If we take the experimental investment as a reference point (EUR 810 for each of the establishments), it can be seen that it represents approximately slightly less than a third of the investment made if we consider that the experiment was carried out in three daily periods of two hours each, which can be extrapolated to the rest of the time slots.

After the exploitation of the sensory elements, the image of the shop improved considerably, growing in attractiveness; therefore, it is necessary to highlight that the increase in sales and satisfaction could mean a highly probable increase in the volume of frequent customers thanks to the changes made in the store. This, in the final analysis, is an indication that customers like the shop and what it is offering in many aspects.

For all these reasons, and in general terms, we can conclude that, based on the set goals of this research, the application of sensory marketing to Aristocrazy was successful in the three items set out in the research, especially bearing in mind that, in terms of profitability (which is what usually really matters to the managers of commercial establishments), the objective was more than achieved since, as we pointed out earlier, almost a third of the investment was recovered in just three two-hour slots on three different days. It would be unwise to state with certainty that the investment would be inexorably recouped within seven days, but it is highly likely that the economic cost of the changes can be regained within the same month, so that in all aspects we consider the Hulten, Broweus and Van Dijk model to be valid and reliable for a small retail outlet.

It has also been concluded that the Hulten, Broweus and Van Dijk model is not only valid and reliable for a commercial establishment such as the one studied at this time of pandemic recession (COVID-19), but that this finding agrees with the literature written in recent years showing that this type of commercial strategy can significantly contribute to the optimisation of energy resources $[18,19,55]$. Similar recent studies in other geographical areas and with different products have proved this to be true $[65,67-69]$. Thus, the validity and reliability of the experiment can also be verified in periods of economic, social and 
health crisis. Moreover, it should be noted that there is a (direct and indirect) relationship between energy resources and the sensory marketing campaign. In this sense, we provided some specific data; for example, through this campaign a series of fundamental energy resources can be saved. This might include electricity, as with the results obtained, the establishment proposed a reduction in the opening hours to the public. Specifically: to close the point of sale to the public for $2 \mathrm{~h}$ less per day, from 18.30 to $20.30 \mathrm{~h}$. It should be clarified here that in Spain, in winter, dusk begins at $18.15 \mathrm{~h}$, so if sales are generated during daylight hours, electricity consumption (interior and exterior lighting) will be lower, in addition to the reduction in electricity consumption resulting from the use of $2 \mathrm{~h}$ less with the necessary electrical technology made available for physical sales.

Likewise, it is necessary to comment that as part of the limitations of the study, sustained by the restrictions of the sample size (a local case study, but with sufficient basis to represent a research approach), and by the impossibility of contemplating other variables that also directly affect trade such us geographical, temporal, local, demographic etc.), it would be interesting to expand the sample as other studies have done [70], perhaps emphasising the senses that have yielded the best results in other experiments $[71,72]$ or even covering the rest of the sensations as well as emotions [73] to determine whether the model, which has been extensively validated, is still valid in other types of environments.

Author Contributions: Conceptualization, G.J.-M., R.E.Z., A.G.-C. and R.R.-R.; software, G.J.-M., R.E.Z., A.G.-C. and R.R.-R.; formal analysis, G.J.-M., R.E.Z., A.G.-C. and R.R.-R.; investigation, G.J.-M., R.E.Z., A.G.-C. and R.R.-R.; resources, G.J.-M., R.E.Z., A.G.-C. and R.R.-R.; data curation, G.J.-M., R.E.Z., A.G.-C. and R.R.-R.; writing—original draft preparation, G.J.-M., R.E.Z., A.G.-C. and R.R.-R.; writing-review and editing, G.J.-M., R.E.Z., A.G.-C. and R.R.-R.; visualization, G.J.-M., R.E.Z., A.G.-C. and R.R.-R.; supervision, G.J.-M., R.E.Z., A.G.-C. and R.R.-R.; project administration, G.J.-M., R.E.Z., A.G.-C. and R.R.-R.; funding acquisition, INDESS. All authors have read and agreed to the published version of the manuscript.

Funding: This research received no external funding.

Institutional Review Board Statement: Not applicable.

Informed Consent Statement: Not applicable.

Data Availability Statement: No new data were created or analyzed in this study. Data sharing is not applicable to this article.

Conflicts of Interest: The authors declare no conflict of interest. The funders had no role in the design of the study; in the collection, analysis, or interpretation of data; in the writing of the manuscript; or in the decision to publish the results.

\section{References}

1. Ghosh, D.; Sant, T.G.; Kuiti, M.R.; Swami, S.; Shankar, R. Strategic decisions, competition and cost-sharing contract under industry 4.0 and environmental considerations. Resour. Conserv. Recycl. 2020, 162, 105057. [CrossRef]

2. Kocsi, B.; Maiko Matonya, M.; Pusztai, L.P.; Budai, I. Real-Time Decision-Support System for High-Mix Low-Volume Production Scheduling in Industry 4.0. Processes 2020, 8, 912. [CrossRef]

3. Leong, W.D.; Teng, S.Y.; How, B.S.; Ngan, S.L.; Abd Rahman, A.; Tan, C.P.; Ponnanbalam, S.G.; Lam, H.L. Enhancing the Adaptability: Lean and Green Strategy towards the Industry Revolution 4.0. J. Clean. Prod. 2020, 273, 122870. [CrossRef]

4. Masood, T.; Sonntag, P. Industry 4.0: Adoption challenges and benefits for SMEs. Comput. Ind. 2020, 121, 103261. [CrossRef]

5. Ravina-Ripoll, R.; Foncubierta-Rodríguez, M.J.; Ahumada-Tello, E.; Evans, R.D. Does Money Makes Entrepreneurs Happy in the Age of Industries 4.0? In Proceedings of the IEEE Technology \& Engineering Management Conference (TEMSCON), Detroit, MI, USA, 3-6 June 2020; pp. 1-5.

6. Weking, J.; Stöcker, M.; Kowalkiewicz, M.; Böhm, M.; Krcmar, H. Leveraging industry 4.0—A business model pattern framework. Int. J. Prod. Econ. 2020, 225, 107588. [CrossRef]

7. Picatoste, J.; Pérez-Ortiz, L.; Ruesga-Benito, S.M. A new educational pattern in response to new technologies and sustainable development. Enlightening ICT skills for youth employability in the European Union. Telemat. Inform. 2018, 35, 1031-1038. [CrossRef]

8. Ghadge, A.; Kara, M.E.; Moradlou, H.; Goswami, M. The impact of Industry 4.0 implementation on supply chains. J. Manuf. Technol. Manag. 2020, 31, 669-686. [CrossRef] 
9. Müller, J.M.; Buliga, O.; Voigt, K.I. The role of absorptive capacity and innovation strategy in the design of industry 4.0 business Models-A comparison between SMEs and large enterprises. Eur. Manag. J. 2020, in press. [CrossRef]

10. Nguyen, D.H.; Leeuw, S.; Dullaert, W.E.H. Consumer Behaviour and Order Fulfilment in Online Retailing: A Systematic Review. Int. J. Manag. Rev. 2018, 20, 255-276. [CrossRef]

11. Zhang, Y.; Fang, Y.; Wei, K.K.; Ramsey, E.; McCole, P.; Chen, H. Repurchase intention in B2C e-commerce-A relationship quality perspective. Inf. Manag. 2011, 48, 192-200. [CrossRef]

12. Childs, M.; Jin, B.E. Retailer-brand collaborations: Testing key strategies to increase consumers' urgency to buy. Int. J. Retail. Distrib. Manag. 2020, 48, 380-394. [CrossRef]

13. Jiménez-Marín, G. Commercial distribution, retail and marketing mix. The new variables. In Nuevos Tratamientos Informativos y Persuasivos; Mut Camacho, M., Camarero Calandria, E., Eds.; Tecnos: Madrid, Spain, 2017; pp. 113-120.

14. Ramírez Beltrán, C.J.; Alférez Sandoval, L. Conceptual model to determine the impact of visual merchandising on sales purchase decision making. Thought Manag. 2014, 36, 1-27.

15. Sánchez-Franco, M.J. Eficacia Publicitaria: Teoría y Práctica; McGraw Hill: Madrid, Spain, 1999.

16. Kireev, V.S.; Nekrasova, M.L.; Shevchenko, E.V.; Alpatskaya, I.E.; Makushkin, S.A.; Povorina, E.V. Marketing Management as the Realization Process of Research, Production and Sale Activity of the Enterprise. Int. Rev. Manag. Mark. 2016, 6, 228-234.

17. Kim, C.; Takashima, K. Effects of retail organization design on improving private label merchandising. Eur. J. Mark. 2019, 53, 2582-2603. [CrossRef]

18. Jang, H.W.; Lee, S.B. Applying effective sensory marketing to sustainable coffee shop business management. Sustainability 2019, 11, 6430. [CrossRef]

19. Nghiêm-Phú, B. Sensory marketing in an outdoor out-store shopping environment-an exploratory study in Japan. Asia Pac. J. Mark. Logist. 2017, 29, 994-1016. [CrossRef]

20. Krampe, C.; Strelow, E.; Haas, A.; Kenning, P. The application of mobile fNIRS to "shopperneuroscience"-Firstinsights from a merchandising communication study. Eur. J. Mark. 2018, 52, 244-259. [CrossRef]

21. Liu, X.; Kim, C.-S.; Hong, K.-S. An fNIRS-based investigation of visual merchandising displays for fashion stores. PLoS ONE 2018, 13, e0208843. [CrossRef] [PubMed]

22. Lindstrom, M. Brand Sense; Simon \& Schuster: New York, NY, USA, 2008.

23. Lindstrom, M. Buying Addiction: Truths and Lies about Why People Buy; Norma: Bogotá, Colombia, 2009.

24. Sheen Moreno, M.J.; Arbaiza, F. The use of cultural identity in advertisements to strengthen the consumer-brand relationship. J. Commun. 2020, 19, 285-301.

25. Alexandre Silva de Quevedo, A.; Müller Quevedo, D.; Schmitt Figueiró, P.; Kerli Fernandesl, E. Neuromarketing as an Environmental Awareness Tool: The Sustainable Consumption. In Anthropological Approaches to Understanding Consumption Patterns and Consumer Behavior; Valentina Chkoniya, V., Oliveira Madsen, A., Bukhrashvili, P., Eds.; IGI Global: Hershey, PA, USA, 2020.

26. Zhu, R.; Meyers-Levy, J. Distinguishing between the Meanings of Music: When Background Music Affects Product Perceptions. J. Mark. Res. 2005, 42, 333-345. [CrossRef]

27. Pradeep, A.K. The Buying Brain: Secrets for Selling to the Subconscious Mind; John Wiley \& Sons: Hoboken, NJ, USA, 2010.

28. Bonadeo, M. Odotipo: Historia Natural del Olfato y su Función en la Identidad de Marca; Austral University: Buenos Aires, Argentina, 2005.

29. Schmitt, B. Experiential Marketing; Deusto: Barcelona, Spain, 2006.

30. Singhal, S.; Khare, K. Does Sense Reacts for Marketing-Sensory Marketing. Int. J. Manag. IT Eng. 2015, 5, 1-18. [CrossRef]

31. Schmitt, B. Customer Experience Management (CEM); Mcgraw-Hill: México DF, Mexico, 2003.

32. Gobé, M. Emotional Branding. The New Paradigm for Connecting Brands Emotionally with People; Divine Egg: Barcelona, Spain, 2005.

33. Hulten, B.; Broweus, N.; Van Dijk, M. Sensory Marketing; Palgrave Macmillan: London, UK, 2009.

34. Álvarez del Blanco, R. Perfect fusion: Neuromarketing; Prentice Hall: Barcelona, Spain, 2011.

35. Gómez, M.; García, C. The use of sensorial marketing in stores: Attracting clients through the senses. In Advances in Marketing, Customer Relationship Management, and E-Services; Musso, F., Druica, E., Eds.; Hershey: Derry Township, PA, USA, 2014; pp. 64-78.

36. Ortegón, L.O.; Vela, M.R.; Pinzón, Ó.J.R. Children's consumer behaviour: Recall and preference of sensory attributes of brands and lunchbox products in children in Bogotá. Poliantea 2015, 11, 39-64.

37. Krishna, A.; Schwarz, N. Sensory marketing, embodiment, and grounded cognition: A review and introduction. J. Consum. Psychol. 2014, 24, 159-168. [CrossRef]

38. Cant, M.C.; Hefer, Y. Visual Merchandising Displays-Functional or a Waste of Space in Apparel Retail stores? Gender Behavious 2013, 11, 5336-5341.

39. Butt, J. Exploring the interrelationship between additive manufacturing and Industry 4.0. Designs 2020, 4, 13-24. [CrossRef]

40. Roblek, V.; Meško, M.; Krapež, A. A complex view of industry 4.0. Sage Open 2016, 6, 2. [CrossRef]

41. Jaffe, A.B.; Newell, R.G.; Stavins, R.N. A tale of two market failures: Technology and environmental policy. Ecol. Econ. 2005, 54, 164-174. [CrossRef]

42. Reischauer, G. Industry 4.0 as policy-driven discourse to institutionalize innovation systems in manufacturing. Technol. Forecast. Soc. Chang. 2018, 132, 26-33. [CrossRef]

43. Chiarini, A. Industry 4.0, quality management and TQM world. A systematic literature review and a proposed agenda for further research. TQM J. 2020, 32, 603-616. [CrossRef] 
44. Lass, S.; Gronau, N. A factory operating system for extending existing factories to Industry 4.0. Comput. Ind. 2020, 115, 103128. [CrossRef]

45. Xu, L.D.; Xu, E.L.; Li, L. Industry 4.0: State of the art and future trends. Int. J. Prod. Res. 2018, 56, 2941-2962. [CrossRef]

46. Borissova, V. Digital Transformation for Digital Competitiveness at a Micro Level. Econ. Stud. J. 2021, 1, 89-106.

47. Valenti, C.; Riviere, J. The concept of Sensory Marketing. Mark. Diss. 2008, 12, 32-46.

48. Kuczamer-Kłopotowska, S. Sensory marketing as a new tool of supporting the marketing communication process in tourism services sector. Handel Wewnętrzny 2017, 367, 226-235.

49. Kim, C.H.; Jung, Y.S. A Study on the Effects of Experiential Marketing on Satisfaction, Loyalty and Purchase Intention. Korean J. Bus. Adm. 2018, 31, 603-624.

50. Moreira, A.C.; Fortes, N.; Santiago, R. Influence of sensory stimuli on brand experience, brand equity andpurchase intention. $J$. Bus. Econ. Manag. 2017, 18, 68-83. [CrossRef]

51. Jiménez-Marín, G. Merchandising \& Retail. Communication at the Point of Sale; Advook: Seville, Spain, 2016.

52. $\mathrm{Pu}, \mathrm{X}$; Gong, L.; Han, G. A feasible incentive contract between a manufacturer and hisfairness-sensitive retailer engaged in strategic marketing efforts. J. Intell. Manuf. 2019, 30, 193-206. [CrossRef]

53. Pantano, E.; Laria, G. Innovation in Retail Process: From Consumers' Experience to Immersive Store Design. J. Manag. Innov. 2012, 7, 194-206.

54. Araújo, N. Global economic impact of the covid-19 pandemic. Analysis from the most affected sectors. Quipukamayoc 2020, $28,57$.

55. Warren, P. The potential of smart technologies and micro-generation in UK SMEs. Energies 2017, 10, 1050. [CrossRef]

56. Foncubierta-Rodríguez, M.J.; Ravina-Ripoll, R.; López-Sánchez, J.A. Generational portrait of Spanish society in the face of climate change. A question to consider for the Green Economy under the Well Being. Energies 2021, 14, 807. [CrossRef]

57. Damasio, A. The Feeling of What Happens: Body and Emotion in the Making of Consciousness; Crítica: Barcelona, Spain, 1999.

58. Moktadir, M.A.; Ali, S.M.; Kusi-Sarpong, S.; Shaikh, M.A.A. Assessing challenges for implementing Industry 4.0: Implications for process safety and environmental protection. Process. Saf. Environ. Prot. 2018, 117, 730-741. [CrossRef]

59. Bourikas, L.; Gauthier, S.; Khor Song En, N.; Xiong, P. Effect of Thermal, Acoustic and Air Quality Perception Interactions on the Comfort and Satisfaction of People in Office Buildings. Energies 2021, 14, 333. [CrossRef]

60. Richardson, A. Understanding Customer Experience. Harv. Bus. Rev. 2010, 15, 1-5.

61. Braidot, N. Neuromarketing: Why Do Your Clients Sleep with Someone Else if They Say They Like You? Gestión: Barcelona, Spain, 2008.

62. Tintara, I.; Respati, N.N. The Effect of Product Differentiation, Service Differentiation, and Image Differentiation on Competitive Advantage. Am. J. Humanit. Soc. Sci. Res. 2020, 4, 316-321.

63. Kelley, S.W.; Davis, M.A. Antecedents to customer expectations for service recovery. J. Acad. Mark. Sci. 1994, 22, 52-61. [CrossRef]

64. Fahrur Riza, A.; Marlina Wijayanti, D. The Triangle of Sensory Marketing Model: Does it Stimulate Brand Experience and Loyalty? Esensi Jurnal Bisnis Manaj. 2018, 8, 57-66.

65. Rodas-Areiza, J.A.; Montoya-Restrepo, L.A. Methodological proposal for the analysis and measurement of sensory marketing integrated to the consumer experience. DYNA 2018, 85, 54-59. [CrossRef]

66. Anuario SGAE 2020 de las Artes Escénicas, Musicales y Audiovisuales. 2020.

67. Hussain, S. Sensory Marketing Strategies and Consumer Behavior: Sensible Selling Using All Five Senses. IUP J. Bus. Strategy 2019, 16, 34-44.

68. Ifeanyichukwu, C.; Peter, A. The Role of Sensory Marketing in Achieving Customer Patronagein FastFood Restaurants in Awka. Int. Res. J. Manag. 2018, 5, 155-163.

69. Géci, A.; Nagyová, L.; Rybanská, J. Impact of sensory marketing on consumer's buying behaviour. Potravinárstvo Slovak J. Food Sci. 2017, 11, 709-717. [CrossRef]

70. Errajaaa, K.; Daucéb, B.; Legohérelc, P. Consumer reactions to olfactory congruence with brand image. J. Retail. Consum. Serv. 2020, 52, 101898. [CrossRef]

71. Sandell, K. Olfactory cues and purchase behavior: Consumer characteristics as moderators. Eur. J. Mark. 2019, 53, 1378-1399. [CrossRef]

72. Vega-Gómez, F.I.; Miranda-Gonzalez, F.J; Pérez Mayo, J.; González-López, Ó.R.; Pascual-Nebreda, L. The Scentof Art. Perception, Evaluation, and Behaviour in a Museum in Response to Olfactory Marketing. Sustainability 2020, 12, 1384. [CrossRef]

73. Song, J.; Qu, H. The mediating role of consumption emotions. Int. J. Hosp. Manag. 2017, 66, 66-76. [CrossRef] 